\title{
Prevalence of Diarrhoea Disease Among Infants in an Urban and a Rural Local Government Area in Anambra State, Nigeria: A Comparative Study
}

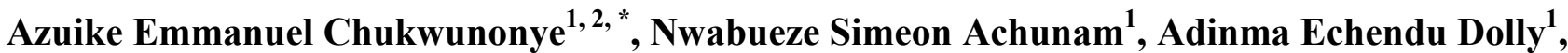 \\ Udedibia Ifeanyi Ndubuisi ${ }^{1,2}$, Onyemachi Prince Ezenwa ${ }^{3}$, Igwebike Uchenna Nwanneka ${ }^{1,2}$, \\ Aniemena Reginald Chidozie ${ }^{1,2}$, Ezenyeaku Chijioke Amara ${ }^{1,2}$, Emerenini Ikenna ${ }^{1,4}$ \\ ${ }^{1}$ Department of Community Medicine, Nnamdi Azikiwe University Teaching Hospital, Nnewi, Nigeria \\ ${ }^{2}$ Foundation for Health and Development in Nigeria, Nnewi, Nigeria \\ ${ }^{3}$ Department of Community Medicine, Abia State University Teaching Hospital, Aba, Nigeria \\ ${ }^{4}$ Faculty of Medicine, Nnamdi Azikiwe University, Awka, Nigeria
}

Email address:

emmanazuike@yahoo.com (E. C. Azuike)

${ }^{*}$ Corresponding author

To cite this article:

Azuike Emmanuel Chukwunonye, Nwabueze Simeon Achunam, Adinma Echendu Dolly, Udedibia Ifeanyi Ndubuisi, Onyemachi Prince Ezenwa, Igwebike Uchenna Nwanneka, Aniemena Reginald Chidozie, Ezenyeaku Chijioke Amara, Emerenini Ikenna. Prevalence of Diarrhoea Disease Among Infants in an Urban and a Rural Local Government Area in Anambra State, Nigeria: A Comparative Study. European Journal of Preventive Medicine. Vol. 4, No. 3, 2016, pp. 56-60. doi: 10.11648/j.ejpm.20160403.11

Received: March 10, 2016; Accepted: March 21, 2016; Published: April 5, 2016

\begin{abstract}
Introduction: Diarrhoea is the $10^{\text {th }}$ most common cause of infant morbidity and mortality in the developing countries, though it is regarded as a minor illness in developed countries. The burden of diarrhoea in the developing world has been estimated by the world health organisation (WHO) to be about $1.7 \times 10^{9}$ episodes of diarrhoea with 4.4 million children per year. This accounts for 15 to $30 \%$ of total outpatient visits in many paediatrics clinics. Aim: To determine the prevalence of diarrhoea disease among infants and compare the risk factors for diarrhoea in infants in the two Local Government Areas (LGAs). Methodology: This was a comparative cross-sectional study. An interviewer-administered, pre-tested, semi-structured questionnaire was utilized. Data was analysed using SPSS Version 20. Frequencies and percentages were presented in tables. Chi square test of independence was used to determine association between qualitative variables. Level of statistical significance was set at $\mathrm{p}<0.05$. Result: Two hundred and ninety one respondents participated in this study. There were 143 respondents in the urban LGA and 148 respondents in the rural LGA. In the urban LGA, Out of the 143 infants, 73 (51.0\%) were males while $70(49.0 \%)$ were females. Also in the rural LGA there were more males $(50.7 \%)$. This difference was not statistically significant. Out of 143 respondents in the urban LGA 65 (45.5\%) has had diarrhoea but in the rural LGA, out of 148 respondents, $95(64.2 \%)$ have had diarrhoea. This difference was statistically significant. In the urban LGA $46.2 \%$ of the mothers whose infants have had diarrhoea practiced exclusive breast feeding, while in the rural LGA only $26.3 \%$ of the mothers whose infants have had diarrhoea practiced exclusive breast feeding. This difference was not statistically significant. Among the mothers of the urban infants that have had diarrhoea, 93.8\% reported that they practice hand washing after handling child's faeces, but in the rural LGA, only $80.0 \%$ reported that they practice hand washing. This difference was statistically significant. Among the urban mothers whose infants had diarrhoea, 92.3\% wash their hands before meals, but among the rural mothers, only $89 \%$ wash their hands before meals. This difference was statistically significant. Conclusion: Diarrhoea prevalence was higher among infants in the rural LGA. Exclusive breastfeeding was practiced more in the urban than in the rural LGA. We recommended that health education should be intensified in the rural areas.
\end{abstract}

Keywords: Prevalence, Diarrhoea, Infants 


\section{Introduction}

Diarrhoea can be defined as a change in the consistency of the stool to being abnormally loose or fluid and increase in the frequency of stools more than is normal for the age of the child. In infancy the passage of 3 or more loose stools in a day is generally regarded as abnormal. [1] This disorder most times is regarded as a minor illness in the industrialized states but is among the 10 causes of infant morbidity and mortality in developing countries. [1] This high morbidity rate is associated with the cultural beliefs and perception about diarrhoea disease. In a semi-urban community in Brazil diarrhoea is thought to be a symptom of an evil phenomenon, intestinal heat or teething. In some parts of northern Nigeria, diarrhoea is believed to be nature's way of cleaning the body, bad food, evil spirit, bad breast milk, weaning, teething and measles. The Yorubas in south-western Nigeria believe that diarrhoea is caused by house flies, dirty food and water, supernatural forces, witchcraft and sweetened food. Similarly, among Igbo communities, diarrhoea is thought to be caused by sugar or sweetened food, dirty water, dirty food and artificial feed. Also there is a general belief among mothers world-wide, Nigeria inclusive, that diarrhoea is a normal part of growing up, like other milestones, and that this is always due to teething. [1]

These beliefs about the aetiology of diarrhoea affect the health seeking behaviour of mothers when this disorder presents, as care givers tend to seek health care from traditional healers. Because of this, most cases of diarrhoea tend to present late when complications have arisen. The burden of this illness in the developing world has been estimated by the World Health Organisation (WHO) to be about $1.7 \times 10^{9}$ episodes of diarrhoea among 4.4 million children. This accounts for 15 to $30 \%$ of total outpatient visits in many paediatrics clinics. Also it was found that $80 \%$ of the deaths from diarrhoea result from dehydration and those who survive the acute episodes are likely to develop persistent diarrhoea, malnutrition and malabsorption syndrome. [1] Some of the organisms implicated in diarrhoea are: Bacteria (example salmonella, staphylococcus aureus, shigella, pseudomonas, E. coli etc); Virus (example Rotavirus, Coronavirus, Adenovirus, HIV, coxsackie virus, etc); Protozoa (which include entamoeba histolytica, giardia lambia, ascaris and cryptosporidium etc); Miscellaneous causes (include systemic infections like malaria and food allergy).

These organisms can be transmitted through the faeco-oral route through contaminated water and food. There are some risk factors associated with this disorder, namely: SocioEconomic factors ( example poor water supply, poor personal hygiene, improper food preparation, poor weaning practices, etc); Host factors (such as malnutrition, depressed immunity, altered gut ecology); Seasonality, although diarrhoea disease occurs throughout the year in the tropics its prevalence tends to be higher in the cold dry months. Clinically there are 4 types of diarrhoea: Acute watery diarrhoea; Dysenteric diarrhoea; Persistent diarrhoea; Chronic diarrhoea.

\section{Methodology}

The study was conducted in government owed Primary Health Centres located in Anaocha and Idemili North Local Government Areas (LGAs), Anambra state.

Idemili North LGA is an urban LGA made up of 10 towns namely: Abacha, Abatete, Eziowelle, Ideani, Nkpor, Obosi, Ogidi, Oraukwu, Uke and Umuoji. Anaocha is a rural LGA made up of 10 towns namely Aguluzigbo, Agulu, Neni, Ichida, Adazi-ani, Adazi-Enu, Adazi-Nnukwu, Akwaeze, Nri and Obeledu.

The study population was caregivers that access the primary health centres in Anaocha and Idemili North for health care services.

This was a cross-sectional comparative study.

SAMPLE SIZE CALCULATION

Using the formula for calculation of sample size for comparative cross-sectional studies [2].

$$
\mathrm{N}=2 \mathrm{Z}^{2} \mathrm{P}(1-\mathrm{P}) / \mathrm{D}^{2}
$$

Where $\mathrm{Z}=1.96$ at $95 \%$ confidence limit

$\mathrm{P}=$ prevalence taken as $2.7 \%(0.027)$ using a prevalence from a study done in Jos to determine the prevalence of diarrhoea disease and risk factors among infants [3].

$\mathrm{D}=$ Margin of error to be tolerated set as $5 \%(0.05)$

$\mathrm{N}=2 \mathrm{Z}^{2} \mathrm{P}(1-\mathrm{P}) / \mathrm{D}^{2}$

$$
\begin{aligned}
& =2 \times \frac{1.96^{2} \times 0.027(1-0.027)}{0.05^{2}} \\
& =2 \times \frac{3.8416 \times 0.027 \times 0.973}{0.05^{2}}
\end{aligned}
$$

$\mathrm{N}=80.7$

Using an attrition rate of $20 \%$

$20 / 100 \times 80.7=16.1$.

$80.7+16.1=96.8$.

However, in order to improve the power of the study, 291 respondents were enrolled into the study.

\section{SAMPLING TECHNIQUE:}

Multi stage sampling technique was applied. Stage 1: Simple random sampling was used to select one Local Government area from the 7 urban LGAs in Anambra state. Also simple random sampling was applied to select one rural LGA out of the 14 rural LGAs in Anambra State. Stage 2: Simple random sampling was applied to select 2 towns from the urban LGA. Also simple random sampling was applied to select 2 towns from the rural LGAs. Stage 3: All the primary health centres in the selected communities were used for this study.

\section{DATA COLLECTION}

The data was collected using a semi-structured interviewer-administered questionnaire.

DATA ANALYSIS

The data was analysed using SPSS statistical software. Frequencies and percentages were presented in tables. Chisquare test was used to determine association between categorical variables.

INCLUSION \& EXCLUSION CRITERIA 
All care givers with infants accessing care at the primary health centres in Anaocha and Idemili North LGAs in Anambra State during the period of the study were included. All caregivers with children older than 12 months of age accessing care at the primary health centres in Anaocha and Idemili North LGAs during the period of the study were excluded from the study.

\section{LIMITATIONS}

The study was limited to caregivers accessing care at the Primary Health Centres.

\section{ETHICAL CONSIDERATION}

Ethical approval was obtained from the Nnamdi Azikiwe University Teaching Hospital Ethical Committee. Also consent was obtained from the caregivers before questionnaires were administered.

\section{Results}

Table 1. Sociodemographic chararacteristics.

\begin{tabular}{|c|c|c|c|c|c|}
\hline Variables & Location & & & $\mathrm{X}^{2}$ & p-value \\
\hline & Urban & Rural & Total & & \\
\hline \multicolumn{6}{|l|}{ Gender } \\
\hline Female & $70(49.0)$ & $73(49.3)$ & $143(49.1)$ & 0.004 & 0.25 \\
\hline Male & $73(51.0)$ & $75(50.7)$ & $148(50.9)$ & & \\
\hline Total & $143(100.0)$ & $148(100.0)$ & $291(100.0)$ & & \\
\hline \multicolumn{6}{|l|}{ Age (months) } \\
\hline $0-2$ & $32(22.4)$ & $32(21.6)$ & $64(22.0)$ & 12.280 & 0.025 \\
\hline $3-5$ & $36(25.1)$ & $54(36.5)$ & $90(30.9)$ & & \\
\hline $6-8$ & $31(21.7)$ & $39(26.4)$ & $70(24.1)$ & & \\
\hline $9-12$ & $44(30.8)$ & $23(15.5)$ & $67(23.0)$ & & \\
\hline Total & $143(100.0)$ & $148(100.0)$ & $291(100.0)$ & & \\
\hline \multicolumn{6}{|c|}{ Mother's educational level } \\
\hline None & $0(0.0)$ & $31(20.9)$ & $31(10.7)$ & 1.516 & 0.995 \\
\hline Primary & $33(23.1)$ & $26(17.6)$ & $59(20.3)$ & & \\
\hline Secondary & $65(45.5)$ & $65(43.9)$ & $130(44.6)$ & & \\
\hline Tertiary & $45(31.4)$ & $26(17.6)$ & $71(24.4)$ & & \\
\hline Total & $143(100.0)$ & $148(100.0)$ & $291(100.0)$ & & \\
\hline \multicolumn{6}{|c|}{ Mother's occupation } \\
\hline House wife & $37(25.9)$ & $70(47.3)$ & $107(36.8)$ & 2.06 & 0.895 \\
\hline Trader & $50(35.0)$ & $35(23.7)$ & 85 (29.2) & & \\
\hline Civil servant & $33(23.1)$ & $22(14.9)$ & $55(18.9)$ & & \\
\hline Artisan & $23(16.0)$ & $21(14.1)$ & $44(15.1)$ & & \\
\hline Total & $143(100.0)$ & $148(100.0)$ & $291(100.0)$ & & \\
\hline
\end{tabular}

Table 1 shows the sociodemographic characteristics of the respondents. In the urban LGA, Out of the 143 infants, 73 $(51.0 \%)$ were males while $70(49.0 \%)$ were females. Also in the rural LGA there were more males $(50.7 \%)$. This difference was not statistically significant $\left(\mathrm{X}^{2}=0.004, \mathrm{p}=0.25\right)$. In the urban LGA the commonest age group was the 9-12 months age group (30.8\%), but in the rural LGA, the commonest age group was the 3-5 months age group (36.5\%). This difference was statistically significant $\left(\mathrm{X}^{2}=12.280, \mathrm{p}=0.025\right)$. In the urban LGA, the commonest educational level of the mothers was the secondary education $(45.5 \%)$, also in the rural area, the commonest educational level of the mothers was secondary education $(43.9 \%)$. This difference was not statistically significant $\left(\mathrm{X}^{2}=1.516, \mathrm{p}=0.995\right)$. In the urban LGA, the commonest occupation of the mothers was trading (50\%), while in the rural LGA the commonest occupation of the mothers was house wife $(70 \%)$. This difference was not statistically significant $\left(\mathrm{X}^{2}=2.06, \mathrm{p}=0.895\right)$.

Table 2. Prevalence of diarrhoea among infants in the 2 LGAs.

\begin{tabular}{|c|c|c|c|c|}
\hline \multirow{3}{*}{$\begin{array}{l}\text { Have your } \\
\text { child had } \\
\text { diarrhoea since } \\
\text { delivery? }\end{array}$} & \multicolumn{4}{|c|}{ Local government } \\
\hline & Urban & Rural & Chi-square & p-value \\
\hline & $\begin{array}{l}\text { Frequency } \\
(\%)\end{array}$ & $\begin{array}{l}\text { Frequency } \\
(\%)\end{array}$ & & \\
\hline Yes & $65(45.5)$ & $95(64.2)$ & 7.040 & 0.010 \\
\hline No & $78(54.5)$ & $53(35.8)$ & & \\
\hline Total & $143(100.0)$ & $148(100.0)$ & & \\
\hline
\end{tabular}

Table 2 shows that out of 143 respondents in the urban LGA $65(45.5 \%)$ has had diarrhoea but in the rural LGA, out of 148 respondents, $95(64.2 \%)$ have had diarrhoea. This difference was statistically significant $\left(X^{2}=7.040, p\right.$-value $\left.=0.010\right)$.

Table 3. Knowledge on how one gets diarrhoea among caregivers whose infants has had diarrhoea.

\begin{tabular}{|c|c|c|c|c|}
\hline & \multicolumn{4}{|c|}{ Local government } \\
\hline & Urban & Rural & $\mathrm{X}^{2}$ & p-value \\
\hline & $\begin{array}{l}\text { Frequency } \\
(\%)\end{array}$ & $\begin{array}{l}\text { Frequency } \\
(\%)\end{array}$ & & \\
\hline $\begin{array}{l}\text { Staying near someone } \\
\text { having diarrhoea }\end{array}$ & $8(12.3)$ & $4(4.2)$ & 3.77 & 0.123 \\
\hline Eating spoilt food & $8(12.3)$ & 17 (17.9) & & \\
\hline Eating exposed food & $26(40.0)$ & $7(7.4)$ & & \\
\hline $\begin{array}{l}\text { Not washing hands after } \\
\text { going to toilet or after } \\
\text { contact with faeces }\end{array}$ & $15(23.1)$ & $44(46.3)$ & & \\
\hline Drinking unclean water & $4(6.2)$ & $13(13.7)$ & & \\
\hline Multiple answer & $4(6.2)$ & $10(10.5)$ & & \\
\hline Total & 65 & 95 & & \\
\hline
\end{tabular}

Table 3 shows that out of 65 mothers whose infants had diarrhoea in the urban LGA, $26(40 \%)$ had the notion that eating exposed food causes diarrhoea, 15 (23.1\%) believed that contact with faeces or not washing hands after going to toilet causes diarrhoea, $8(12.3 \%)$ indicated eating spoilt food, another $8(12.3 \%)$ indicated staying near someone having diarrhoea, while $4(6.2 \%)$ and another $4(6.2 \%)$ indicated drinking unclean water and multiple answers respectively.

Out of 95 mothers in the rural LGA whose infants had diarrhoea, 44 (46.3\%) had the notion that not washing hands after going to toilet or after contact with faeces causes diarrhoea, followed by eating spoilt food 17 (17.9\%), drinking unclean water $13(13.7 \%)$, those that had multiple answer were $10(10.5 \%)$, then eating exposed food 7(7.4\%) and $4(4.2 \%)$ believed that diarrhoea can be contracted by staying near someone having diarrhoea. This difference was not statistically significant $\left(\mathrm{X}^{2}=3.77\right.$ and $\mathrm{p}$-value $\left.=0.345\right)$

Table 4. Breast feeding pattern among caregivers.

\begin{tabular}{lllll}
\hline \multicolumn{5}{l}{ Local government } \\
\hline & Urban & Rural & $\mathbf{X}^{\mathbf{2}}$ & p-value \\
\hline & Frequency (\%) & Frequency (\%) & & \\
\hline $\begin{array}{l}\text { Exclusive } \\
\text { breast feeding }\end{array}$ & $30(46.2)$ & $25(26.3)$ & 0.927 & 0.06 \\
$\begin{array}{l}\text { No exclusive } \\
\text { breast feeding } \\
\text { Total }\end{array}$ & $35(53.8)$ & $70(73.7)$ & & \\
\hline
\end{tabular}


Table 4 shows that in the urban LGA $46.2 \%$ of the mothers whose infants have had diarrhoea observed exclusive breast feeding while $35 \%$ did not observed exclusive breast feeding. In the rural LGA $26.3 \%$ of the mothers whose infants have had diarrhoea observed exclusive breast feeding while $73.3 \%$ did not observe exclusive breast feeding. This difference was not statistically significant $\left(\mathrm{X}^{2}=0.927 ; \mathrm{p}\right.$ - value $\left.=0.06\right)$.

Table 5. Practices that affect diarrhoea in infants among infants that have had diarrhea.

\begin{tabular}{|c|c|c|c|c|c|}
\hline Practice & Location & & & $X^{2}$ & $\begin{array}{l}p- \\
\text { value }\end{array}$ \\
\hline & $\begin{array}{l}\text { Urban } \\
\text { Frequency } \\
(\%)\end{array}$ & $\begin{array}{l}\text { Rural } \\
\text { Frequency } \\
(\%)\end{array}$ & $\begin{array}{l}\text { Total } \\
\text { Frequency } \\
(\%)\end{array}$ & & \\
\hline \multicolumn{6}{|c|}{ Use of Feeding bottle } \\
\hline Yes & $49(75.4)$ & $47(49.5)$ & $96(60)$ & \multirow[t]{3}{*}{2.312} & \multirow[t]{3}{*}{0.071} \\
\hline No & $16(24.6)$ & $48(50.5)$ & $64(40)$ & & \\
\hline Total & $65(100.0)$ & $95(100.0)$ & $160(100.0)$ & & \\
\hline \multicolumn{6}{|c|}{ Feeding the infant with leftover food } \\
\hline Yes & $9(13.8)$ & $16(16.8)$ & $25(15.6)$ & \multirow[t]{3}{*}{3.453} & \multirow[t]{3}{*}{0.031} \\
\hline No & $56(86.2)$ & $79(83.2)$ & $135(84.4)$ & & \\
\hline Total & $65(100.0)$ & $95(100.0)$ & $160(100.0)$ & & \\
\hline \multicolumn{6}{|c|}{ Hand washing after handling child's faeces } \\
\hline Yes & $61(93.8)$ & $76(80.0)$ & $137(85.6)$ & \multirow[t]{4}{*}{4.512} & \multirow[t]{4}{*}{0.041} \\
\hline No & $3(4.6)$ & $6(6.3)$ & $9(5.6)$ & & \\
\hline Not sure & $1(1.5)$ & $13(13.7)$ & $14(8.8)$ & & \\
\hline Total & $65(100.0)$ & $95(100.0)$ & $160(100.0)$ & & \\
\hline \multicolumn{6}{|c|}{ Source of drinking water } \\
\hline Stream & $16(24.6)$ & $7(7.4)$ & $23(14.4)$ & \multirow[t]{2}{*}{2.456} & \multirow[t]{2}{*}{0.035} \\
\hline Borehole & $23(35.4)$ & $33(34.7)$ & $56(35.0)$ & & \\
\hline $\begin{array}{l}\text { Boiled } \\
\text { water }\end{array}$ & $15(23.1)$ & $40(42.1)$ & $55(34.4)$ & & \\
\hline $\begin{array}{l}\text { Satchet } \\
\text { water }\end{array}$ & $11(16.9)$ & $15(15.8)$ & $26(16.3)$ & & \\
\hline Total & $65(100.0)$ & $95(100.0)$ & $160(100.0)$ & & \\
\hline \multicolumn{6}{|c|}{ Hand washing before eating } \\
\hline Yes & $60(92.3)$ & $85(89.5)$ & $145(90.6)$ & \multirow[t]{3}{*}{5.142} & \multirow[t]{3}{*}{0.040} \\
\hline No & $5(7.7)$ & $10(10.5)$ & $15(9.4)$ & & \\
\hline Total & $65(100.0)$ & $95(100.0)$ & $160(100.0)$ & & \\
\hline \multicolumn{6}{|c|}{ Method of disposal of child's faeces } \\
\hline $\begin{array}{l}\text { Water } \\
\text { closet }\end{array}$ & $41(63.1)$ & $10(10.5)$ & $51(31.9)$ & \multirow[t]{5}{*}{7.326} & \multirow[t]{5}{*}{0.021} \\
\hline Pit latrine & $10(15.4)$ & $28(29.5)$ & $38(23.8)$ & & \\
\hline Bush & $3(4.6)$ & $50(52.6)$ & $53(33.1)$ & & \\
\hline Dustbin & $11(16.9)$ & $7(7.4)$ & $18(11.3)$ & & \\
\hline Total & $65(100.0)$ & $95(100.0)$ & $160(100.0)$ & & \\
\hline
\end{tabular}

Table 5 shows the distribution of some practices that affect diarrhoea in infants. Among the urban infants that have had diarrhoea, $75.4 \%$ were bottle fed, but in the rural infants that have had diarrhoea, $49.5 \%$ were bottle fed. This difference was not statistically significant $\left(\mathrm{X}^{2}=2.312, \mathrm{p}=0.071\right)$. Among the urban infants that have had diarrhoea, $13.8 \%$ were fed left over food, but in the rural LGA, $16.8 \%$ were fed left over food. This difference was statistically significant $\left(\mathrm{X}^{2}\right.$ $=3.453, \mathrm{p}=0.031)$. Among the mothers of the urban infants that have had diarrhoea, $93.8 \%$ reported that they practice hand washing after handling child's faeces, but in the rural LGA, only $80.0 \%$ reported that they practice hand washing.
This difference was statistically significant $\left(\mathrm{X}^{2}=4.512, \mathrm{p}=\right.$ 0.041). In the urban LGA, the commonest source of drinking water was borehole $(35.4 \%)$ but in the rural LGA, the commonest source of drinking water was boiled water (23.1\%). This difference was statistically significant $\left(\mathrm{X}^{2}=\right.$ $2.456, \mathrm{p}=0.035)$. Among the urban mothers whose infants had diarrhoea, $92.3 \%$ wash their hands before meals, but among the rural mothers, only $89 \%$ wash their hands before meals. This difference was statistically significant $\left(\mathrm{X}^{2}=\right.$ 5.142, $\mathrm{p}=0.041)$. Among the urban mothers, the commonest method of disposal of their child's faeces was water closet $(63.1 \%)$, but among the rural mothers, the commonest method was throwing into the bush $(52.6 \%)$. This difference was statistically significant $\left(\mathrm{X}^{2}=7.326, \mathrm{p}=0.021\right)$.

\section{Discussion}

A total of 291 respondents participated in this study. Out of the 291 respondents, 143 were from Idemili North (Urban LGA) and 148 were from Anaocha (Rural LGA). The prevalence of diarrhoea disease among infants in the urban LGA and the rural LGA were $45.5 \%$ and $64.2 \%$ respectively. This lower prevalence of diarrhoea in the urban LGA and higher prevalence of diarrhoea in the rural LGA agrees with the findings of a study done in South west Ethiopia, which reported $6.4 \%$ prevalence for model households and $25.5 \%$ prevalence for non-model households [4]. Majority of the mothers, $73.5 \%$ from the urban LGA and $81.0 \%$ from the rural LGA whose children had diarrhoea were house wives and traders. This agrees with the work done at Southwest Ethiopia, 28.1\% for model and 97.4\% non-model mother [4]. There was a statistically significant association between diarrhoea disease and rural dwelling. Similarly a work done in Dhaka, Bangladesh also reported that there was an association between rural dwelling and diarrhoea in infants [5]. This higher prevalence of diarrhoea in the rural LGA could be attributed to poor hygiene and lack of potable water.

There was a higher percentage of infants in the urban LGA who were fed with feeding bottle $(75.4 \%)$ compared to infants in the rural LGA $(49.5 \%)$. However this difference was not statistically significant $\left(\mathrm{X}^{2}=2.312, \mathrm{p}=0.071\right)$. The higher practice of bottle feeding among the urban respondents may be because the urban mothers are more of working class ladies who find bottle feeding more convenient and time saving. It is worthy of note that despite the higher prevalence of bottle feeding in the urban LGA, there was higher prevalence of diarrhoea in the rural LGA. This may be because the urban mothers being more educated, actually ensure the cleanliness of their feeding bottles.

In this study, among the infants that have had diarrhoea in the urban area, $46.5 \%$ were exclusively breastfed, but in the rural area only $26.5 \%$ of the infants that have had diarrhoea were exclusively breastfed. This may be because the urban women being more educated understood the importance of exclusive breastfeeding and actually practice it more than the rural women. In Bangladesh it was reported that lack of exclusive breastfeeding increased the odds of diarrhoea in 
infants [6]. This could be the reason the prevalence of diarrhoea was higher among the rural infants.

In this study $75.4 \%$ of the urban mothers whose children had diarrhoea practiced bottle feeding, but only $49.5 \%$ of the rural mothers practiced bottle feeding, however this difference was not statistically significant $\left(\mathrm{X}^{2}=2.312, \mathrm{p}=\right.$ 0.071). This finding is not surprising because it is expected that more urban mothers are likely to be working mothers who are more likely to practice bottle feeding because of their work schedule. Greater than sixteen percent of the rural mothers feed their infants left over food, but among the urban mothers, only $13.8 \%$ feed their infants left over food. This difference was statistically significant $\left(\mathrm{X}^{2}=3.453, \mathrm{p}=\right.$ 0.031). Among the urban mothers, $93.8 \%$ wash their hands after handling their child's feaces, but among the rural mothers, only $80 \%$ wash their hands after handling child's faeces $\left(X^{2}=4.512, p=0.041\right)$. Also $92.3 \%$ of the urban mothers practiced hand washing before eating while $89.5 \%$ of the rural mothers practiced hand washing before eating which was also statistically significant $\left(X^{2}=5.142, p=\right.$ 0.040). This lower level of hand washing among the rural mothers may be one of the reasons the prevalence of diarrhoea was higher in the rural area. A systematic review published in the Lancet reported that hand washing can reduce the risk of diarrhoea by $42-47 \%$ [7]. Also an interventional study done in Bangladesh reported a 2.6 fold reduction in diarrhoeal episodes in a community following institution of hand washing [8].

In this study a little above sixty three percent of the urban mothers dispose their child's faeces into the water closet but among the rural mothers only $10.5 \%$ dispose into the water closet. This difference was statistically significant $\left(\mathrm{X}^{2}=\right.$ $7.326, p=0.021)$. Similarly a study done in Brazil reported that absence of water closet was significantly associated with increased risk of death from diarrhoea among infants [9].

Based on the above findings we recommend as follows: Female education should be intensified in the rural areas. Health education on exclusive breastfeeding should be intensified in the rural areas. Feeding of children with leftover food should be discouraged. Provision of potable water and water closet in the rural areas should be considered a matter of urgent importance by government.

\section{References}

[1] Azubike JC, Kanu. E. O. Nkamginieme. disorders of gastrointestinal tract. Paediatrics and Child Health in a Tropical Region, Second edition. 2007; 275-277.

[2] Araoye M. O, Research Methodology with statistics for health and social science. First edition. Natuadex publishers, Ilorin $2003 ; 118$.

[3] Yalgwan CS, Okolo SN. Prevalence of diarrhea disease and risk factors in Jos university Teaching Hospital, Nigeria. Annals of African Medicine 2012. 11(4): 217-21

[4] Teklemichael Gebru, Mohammed Taha and Wondwosen Kassahum. Risk factors of diarrhea disease in under-five children among health extension model and non-model families in Sheko district rural community, Southwest Ethiopia: Comparative cross-sectional study. BMC Public Health 2014, 14: 395.

[5] Fefkrdous F, Da Sk, Ahmed S, Farzana FD, Malek MA, Das J, latham JR, Faruque AS, Christi MJ. Diarrhoea in slum children: observation from a large diarrhoeal disease hospital in Dhaka, bangledash. Pubmed 2014: 19(10) 1170-6

[6] Seema Mihrshahi, Wendy H Oddy, Jennifer K peat and Iqbal kabir. Association between infants feeding patterns and diarrhoeal and respiratory illness. A cohort study in Chittagong, Bangledash. google International breastfeeding journal 2008.24; 3:28

[7] Curtis C, Cairncross S. Effect of washing hands with soap on diarrhoea risk in the community: a systematic review. Lancet Infect Dis 2003; 3: 275-81.

[8] Shahid NS, Greenough WB, Samadi AR, Huq MI, Rahman N. Hand washing with Soap reduces diarrhoea and spread of bacterial pathogens in a Bangladesh village. Journal of Diarrhoeal Diseases Research, 1996, 14(2): 85-89.

[9] Victoria CG, Smith PG, Vaughan JP, Nobre LC, Lombardi C, Teixeira AM, Fuchs SC, Moreira LB, Gigante LP, Barros FC. Water supply, sanitation and housing in relation to the risk of infant mortality from diarrhea. International Journal of Epidemiology, 1988; 17 (3): 651-4. 